\title{
Photosynthetic Pigments Contained in Surface Sediments from the Hydrothermal System of Guaymas Basin, Gulf of California
}

\author{
D. B. Ramírez-Ortega, ${ }^{1}$ L. A. Soto ${ }^{D}{ }^{2}$ A. Estradas-Romero ${ }^{2}{ }^{3}{ }^{3}$ \\ and F. E. Hernández-Sandoval ${ }^{4}$ \\ ${ }^{1}$ UNAM, Circuito, Ciudad Universitaria, Coyoacán, 04510 Ciudad de México, Mexico \\ ${ }^{2}$ Instituto de Ciencias del Mar y Limnología, UNAM, Circuito, Ciudad Universitaria, Coyoacán, 04510 Ciudad de México, Mexico \\ ${ }^{3}$ Facultad de Ciencias. Circuito Exterior s/n, Coyoacán, Ciudad Universitaria, Coyoacán, 04510 Ciudad de México, Mexico \\ ${ }^{4}$ Centro de Investigaciones Biológicas del Noroeste, S.C. Km. 1 Carretera a San Juan de La Costa "EL COMITAN" Apdo. Postal 128, \\ La Paz, BCS 23097, Mexico
}

Correspondence should be addressed to L. A. Soto; lasg@cmarl.unam.mx

Received 15 March 2019; Revised 6 May 2019; Accepted 23 May 2019; Published 1 July 2019

Academic Editor: Horst Felbeck

Copyright @ 2019 D. B. Ramírez-Ortega et al. This is an open access article distributed under the Creative Commons Attribution License, which permits unrestricted use, distribution, and reproduction in any medium, provided the original work is properly cited.

\begin{abstract}
In the exploration of the hydrothermal system of the Guaymas Basin (GB) between $27^{\circ} 00^{\prime} 35^{\prime \prime}$ and $27^{\circ} 00^{\prime} 50^{\prime \prime} \mathrm{N}$ and $111^{\circ} 24^{\prime}$ $15^{\prime \prime}$ and $111^{\circ} 24^{\prime} 40^{\prime \prime} \mathrm{W}$ in the Gulf of California, carried out on the R/V Atlantis and of the DSRV/Alvin in October 2008, four cores of surface sediments were obtained to analyse photosynthetic pigments at two locations with contrasting extreme conditions: Oil Town and Great Pagoda. We identified nine pigments: Chlorophyll- $a$, Phaeophytin- $a$, Phaeophorbide- $a$, Pyropheophytin- $a$ (degradation Chlorophyll- $a$ products), $\beta$-Carotene, Alloxanthin, Zeaxanthin, Diadinoxanthin, and Prasinoxanthin (carotenoids). The maximum pigment concentration was registered in the Great Pagoda (10,309 ng/g) and the minimum in Oil Town (918 ng/g). It is demonstrated that photosynthetic pigment profiles in surface sediments depend on the heterogeneity of the extreme conditions of each site caused mainly by temperature and bacterial substrates. Therefore, there were significant differences $(p<0.05)$ in the pigmentary profile of the four sedimentary cores analyzed. However, no statistical differences $(p>0.05)$ in the concentration of pigments have been detected. We conclude that the photosynthetic pigments contained in the surface sediments of the hydrothermal vents in the Guaymas Basin are primarily of chemoautotrophic bacterial origin.
\end{abstract}

\section{Introduction}

An unusually high heat flow zone characterizes the Gulf of California due to convection currents in the magmatic chamber rising below this region through the Eastern Pacific Rift (EPR) [1]. These propagation mechanisms of the crust in the central Gulf of California, associated with intense tectonic dynamics of the place, give rise to a deep hydrothermal system in the southern part of the Guaymas Basin (GB). The sediments in Guaymas Basin are a mixture of immature, firstcycle erosional detritus, and biogenic material [1]. This system is covered with a sedimentary layer rich in organic matter, with a thickness of approximately $400 \mathrm{~m}$ [2]. It is composed of siliceous material of biogenic origin (mainly of diatoms $>50 \%$ ) and terrigenous sediments rich in plagioclase [3], in addition to the precipitates originated from hydrothermal fluids rich in particulate manganese and dissolved silica $[4,5]$.

Photosynthetic pigments contained in marine sediments are useful indicators of oxidized terrigenous organic matter and eutrophication conditions [6,7] and have also been used in the evaluation of phototrophic communities [8]. Kowalewska [7] mentions that in a sedimentary sequence (0$10 \mathrm{~cm}$ ), the content of pigments in the deep layers is similar and generally lower than in the surface layers and that these differences are caused by (1) sedimentation rates, (2) bacterial degradation, photooxidation, and temperature change in the water column, and (3) primary production.

The general biogeochemical conditions prevailing in GB are reasonably known [1,9-13]. Our current knowledge on the diagenesis of chlorophyll derivatives in the Gulf 


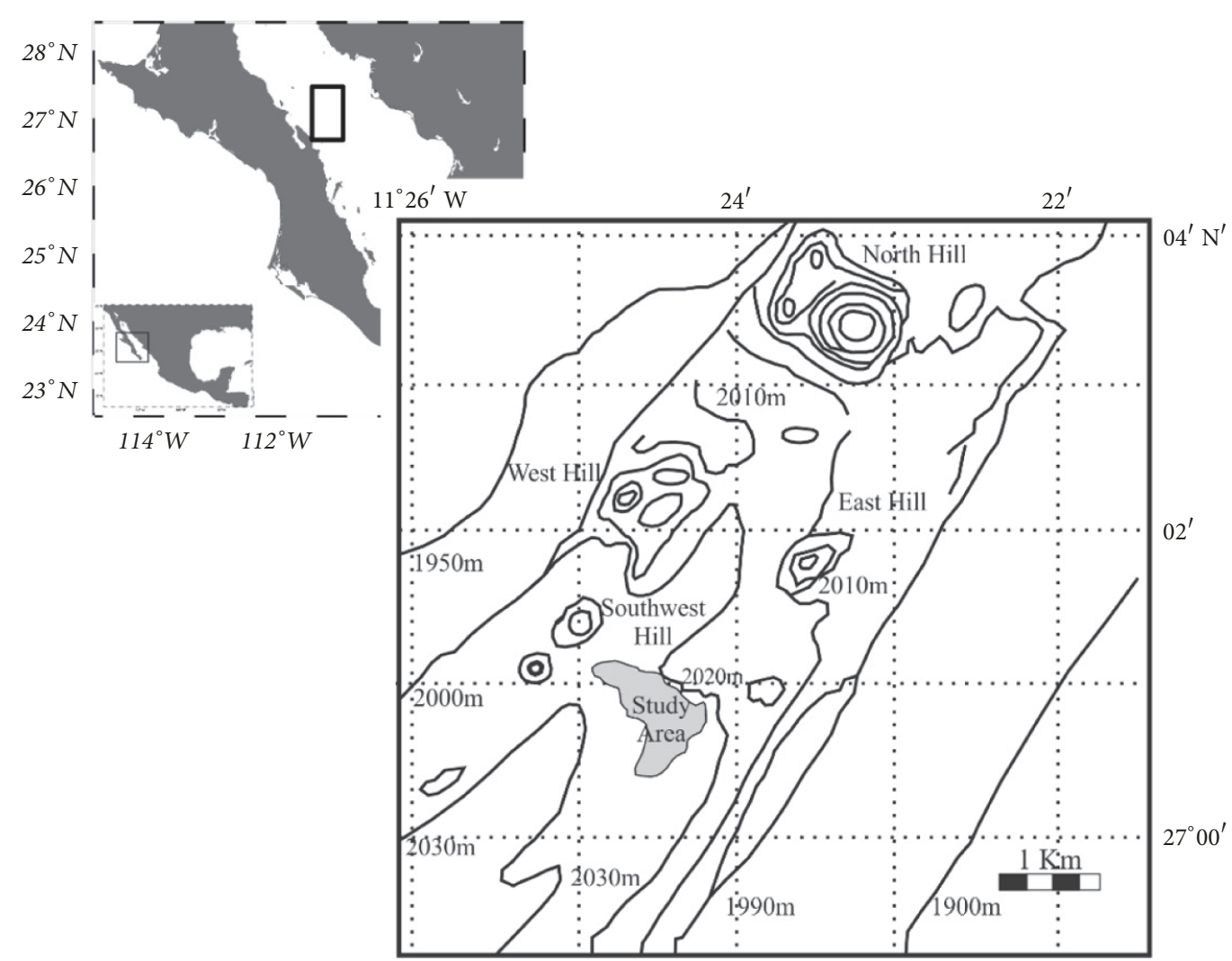

Figure 1: Guaymas Basin (GB) and study area location in the Central Gulf of California. Modified from Soto [13].

of California is restricted to the geochemical analysis of sediments obtained by the Deep Sea Drilling Project Leg 64 [14]. Our study intends to elucidate if the composition and concentration of study's focus is on the class of photosynthetic pigments (tetrapyrrole and tetraterpenoid) contained in and their concentration in surface sediments from two active hydrothermal sites in GB suffered alteration due to the exhibiting contrasting extreme conditions prevailing at each site. We postulate that such conditions may alter the diagenesis of chlorophyll derivatives as potential organic sources for heterotrophs in the studied vent system.

\section{Materials and Methods}

2.1. Study Area. The Guaymas Basin is located in the central part of the Gulf of California between $27^{\circ} 00^{\prime} 35^{\prime \prime}$ and $27^{\circ}$ $00^{\prime} 50^{\prime \prime} \mathrm{N}$ and $111^{\circ} 24^{\prime} 15^{\prime \prime}$ and $111^{\circ} 24^{\prime} 40^{\prime \prime} \mathrm{W}$. It is a semienclosed Basin formed by two (northern and southern) axial troughs bounded by extensive systems of axial-parallel fault lines separated by a fault $20 \mathrm{~km}$ long and 3 to $5 \mathrm{~km}$ wide at a depth of $2,030 \mathrm{~m}$ with temperatures of $2.8^{\circ} \mathrm{C}$ in the bottom [15-18] (Figure 1). The site is distinguished by having a high sedimentation rate greater than 1-1.2 m 1,000 years1 [14] forming a combination of terrigenous detritus and biogenic matter [1]. This high sedimentation rate favours the concentration of considerable organic matter at the bottom of the Basin that is subject to hydrothermal stress $[9,10,14]$.

The most distinctive feature of the Basin is the active hydrothermalism in the Southern Trough formed a complex hydrothermal landscape on the seafloor [19], in which mineral deposits are formed in the form of mounds, spires, pagoda-like structures, and tall pillars distributed over a terrain covered by fine sediment $[9,13]$ which contains a complex mixture of aliphatic and aromatic hydrocarbons that are formed by the hydrothermal alteration of sedimentary organic matter $[11,18,20]$.

One of the sampling sites is the area called "Grand Pagoda." It is a large hydrothermal formation. The area is covered by orange and white Beggiatoa spp. bacterial mats and Riftia colonies, indicating diffuse venting. In the upper part of the formation, it is covered by lobed extensions spreading that extend approximately one meter on each side towards the water column. Small chimneys appeared in the center of some flanges. Part of the hydrothermal fluid flow seeps and rises through the center of small chimneys [16]. The other site, "Old Town," includes sulphide edifices with diffuse flow, bearing clusters of $R$. pachyptila, but notorious for the presence of liquid hydrocarbons in the adjacent sediments.

The presence of organic carbon allows for high biological productivity at the site, despite being a zone of extreme conditions. The conjugation between sulphides and hydrocarbons from hydrothermal discharges provides the necessary energy for the development of a complex hydrothermal biological community whose existence depends on chemosynthetic processes [13, 21].

2.2. Sampling. Four sediment push-cores $(33 \mathrm{~cm}$ length $\mathrm{x} 16$ $\mathrm{cm}$ diameter) were obtained during the AT 15-38 expedition 


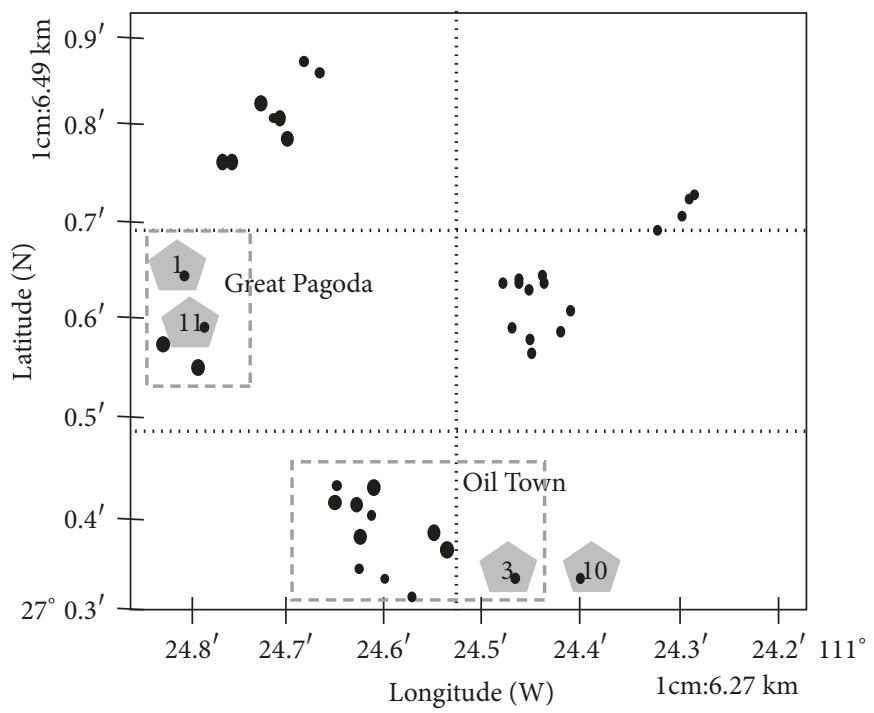

FIgURE 2: Spatial location of sediment cores recovered $(3,10,1$, and 11) by the DSRV-Alvin during the AT 15-38 campaign. • Active sites.

on board of the R/V Atlantis in October 2010 at GB, Gulf of California (Figure 2). The push-cores were recovered by the DSRV-2 Alvin (Woods Hole Oceanographic Institution) during three dives at Oil Town and Great Pagoda located in the Southern Trough. Each site showed different physical characteristics (Table 1). The sediment surface temperature $(0-30 \mathrm{~cm})$ was recorded with the R/V Alvin High-T and LowT probes.

Once on board, the sediments of $\sim 1 \mathrm{~cm}$ from the seafloor were subsampled and stored under dark conditions at $-70^{\circ} \mathrm{C}$ until processed. Pigment analysis was performed according to the method described by Vidussi et al. [22] employing high-performance liquid chromatography (HPLC).

2.3. Pigment Extraction. Five grams of surface sediment from each core was processed. The extractions were made with 4 $\mathrm{cm}^{3}$ of $100 \%$ HPLC grade acetone. The samples were kept in the dark for $24 \mathrm{~h}$ at $-20^{\circ} \mathrm{C}$. They were then centrifuged at 4,000 $\mathrm{rpm}$ for $15 \mathrm{~min}$ at $5^{\circ} \mathrm{C}$. The extract was filtered through in 47 $\mathrm{mm}$ fiberglass membrane and $0.45 \mu \mathrm{m}$ pore size. The volume was recovered in $2 \mathrm{~cm}^{3}$ Eppendorf vials and stored at $-20^{\circ} \mathrm{C}$, $20 \mu \mathrm{L}$; afterward, the volume was injected into the HighPerformance Liquid Chromatograph (Model 1100, Hewlett Packard).

2.4. HPLC Pigment Analysis. A mobile phase was used by mixing two solutions: Solution A: methanol HPLC grade combined with $1 \mathrm{~N}$ aqueous ammonium acetate to form a 70:30 v/v mixture and Solution B: methanol HPLC grade. The separation was carried out in a Hypersil MOS C8 column 100 $\mathrm{x} 4.6 \mathrm{~mm}, 5 \mu \mathrm{m}$ particle size [22]. To identify the pigments, we compared the retention time of the sample peaks with those of the pure standards and the absorption spectra of the problem sample with those of the generated library of the standards (precision $<1 \%$ ). The pigments quantification was done by constructing a calibration curve $\left(R^{2}=\right.$ from 0.9107 tol $)$ that include the concentrations for each standard $(20,30,40$, $50,60$, and $100 \mathrm{ng})$.
2.5. Statistical Analysis. A Chi-square test $\left(\mathrm{X}^{2}\right)$ was performed to determine whether the pigment type depended on the sedimentary core from which the sample was extracted. Similarly, an analysis of variance in a randomized block design (ANDEVA) was applied to assess the existence of significant statistical differences $(p \leq 0.05)$ in the concentration (ng/gr) and in the variety of pigments between the cores. Through Tukey's multiple means comparison test $(p$ $\leq 0.05$ ), the statistical differences between mean pigment concentrations were determined [23].

\section{Results}

3.1. Pigment Identification and Quantification. Nine pigments were identified whose concentrations are listed in Table 2. Six of these photosynthetic pigments corresponded to Chlorophyll- $a$, $\beta$-Carotene, Zeaxanthin, Alloxanthin, Diadinoxanthin, and Prasinoxanthin. The other three pigments, resulting from the Chl- $a$ degradation, were Pyropheophytin$a$, Phaeophytin- $a$, and Phaeophorbide- $a$ (Figure 3). Not all the nine pigments identified were present in a single core.

In four cores, the most abundant Chl- $a$ derivatives were Pyropheophytin- $a$ (3,684 ng/g), which represented $24.6 \%$ of the total concentration of pigments analyzed $(14,962 \mathrm{ng} / \mathrm{g})$, Phaeophorbide- $a$ with $23.2 \%$ (3,478 ng/g), Phaeophytin- $a$ with $7.2 \%(1,074 \mathrm{ng} / \mathrm{g})$, and Chlorophyll- $a$ with $2.6 \%$ (386 $\mathrm{ng} / \mathrm{g}$ ) the least abundant. On the other hand, the predominant carotenoid pigments were Prasinoxanthin (21.5\%, $3,209 \mathrm{ng} / \mathrm{g}), \beta$-Carotene $(14.1 \%, 2,114 \mathrm{ng} / \mathrm{g})$, and Zeaxanthin $(5.6 \%, 841 \mathrm{ng} / \mathrm{g})$. Diadinoxanthin and Alloxanthin had the lowest pigment concentration (168 and $8 \mathrm{ng} / \mathrm{g}$, respectively) (Table 2).

The highest pigment concentration was recorded in core $11(10,309 \mathrm{ng} / \mathrm{g})$ and the lowest in core $3(918 \mathrm{ng} / \mathrm{g})$. Cores 1 and 10 had similar concentrations $(1,876$ and $1,859 \mathrm{ng} / \mathrm{g}$, respectively).

The presence of Phaeophorbide- $a$, Prasinoxanthin, Zeaxanthin, and $\beta$-Carotene was recorded in all the cores 
TABLE 1: Physical characteristics of the sediment samples obtained by the DSRV Alvin in the Guaymas Basin, Gulf of California (Cruise AT 15-38).

\begin{tabular}{lcccc}
\hline DSRV-Alvin Immersion No. & Core & Location & Position \\
\hline 4457 & 3 & Oil Town & $27^{\circ} 00.7039^{\prime} \mathrm{N}$ & $111^{\circ} 24.3179 \mathrm{~W}$
\end{tabular}

Substrate: the temperature recorded in the first $0-20 \mathrm{~cm}$ of depth was $30^{\circ} \mathrm{C}$ (ambient temperature). White and orange bacterial mats were found on surface.

\begin{tabular}{llllll}
\hline 4459 & 10 & Oil Town & $27^{\circ} 00.7039^{\prime} \mathrm{N}$ & $111^{\circ} 24.3179^{\prime} \mathrm{W}$
\end{tabular}

Substrate: the temperature recorded in the first $0-20 \mathrm{~cm}$ of depth was $>200^{\circ} \mathrm{C}$. High concentrations of oil and gas were observed. The external matrix with bacterial growth, consisting of Beggiatoa spp. patches.

$4460 \quad 1 \quad$ Great Pagoda $27^{\circ} 00.67636^{\prime} \mathrm{N} \quad 11^{\circ} 24.416833^{\prime} \mathrm{W}$

Substrate: the temperature has a gradient of 19.2 to $71.0^{\circ} \mathrm{C}$ in the first $6 \mathrm{~cm}$ depth. Orange bacterial mat was found on surface.

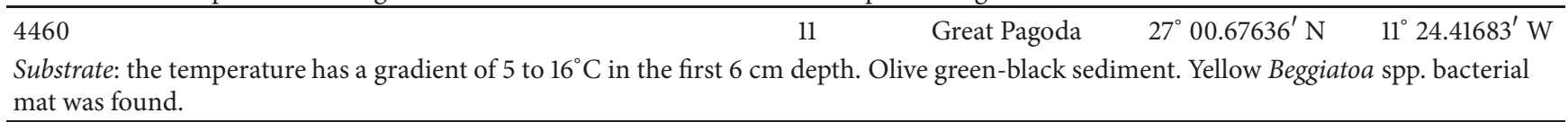

TABLE 2: Retention time ( $\mathrm{min}$ ) and pigment concentration (ng/g) recorded in the sediment cores obtained at the Great Pagoda and Oil Town sites in the Guaymas Basin hydrothermal system. DL = detection limit (ng). A: absent.

\begin{tabular}{|c|c|c|c|c|c|c|}
\hline \multirow{3}{*}{$\begin{array}{l}\text { Pigment Profile } \\
\text { Tetraterpenoid }\end{array}$} & \multirow[t]{3}{*}{ Retention Time } & \multirow[t]{3}{*}{$\mathrm{DL}$} & \multicolumn{4}{|c|}{ Each Pigment Concentration } \\
\hline & & & \multicolumn{2}{|c|}{ Great Pagoda } & \multicolumn{2}{|c|}{ Oil Town } \\
\hline & & & 1 & 11 & 3 & 10 \\
\hline$\beta$-Carotene & 14.7 & 0.14 & 440 & 914 & 341 & 419 \\
\hline Zeaxanthin & 7.98 & 0.44 & 197 & 324 & 99 & 221 \\
\hline Alloxanthin & 7.05 & 0.13 & $\mathrm{~A}$ & $\mathrm{~A}$ & 8 & A \\
\hline Diadinoxanthin & 6.87 & 0.34 & 141 & $\mathrm{~A}$ & 27 & $\mathrm{~A}$ \\
\hline Prasinoxanthin & 6.03 & 0.22 & 820 & 1866 & 213 & 312 \\
\hline \multicolumn{7}{|l|}{ Tetrapyrrole } \\
\hline Chlorophyll- $a$ & 12.39 & 0.23 & A & 298 & $\mathrm{~A}$ & 87 \\
\hline Pyrophaeophytin- $a$ & 14.22 & 1.84 & A & 3514 & 169 & $\mathrm{~A}$ \\
\hline Phaeophytin- $a$ & 13.31 & 2.22 & A & 618 & A & 455 \\
\hline Phaeophorbide- $a$ & 5.02 & 1.36 & 277 & 2775 & 62 & 364 \\
\hline \multicolumn{2}{|c|}{ Pigments Concentration per Core } & & 1876 & 10309 & 918 & 1859 \\
\hline \multicolumn{3}{|c|}{ Pigments Concentration Total } & & & & 14,962 \\
\hline
\end{tabular}

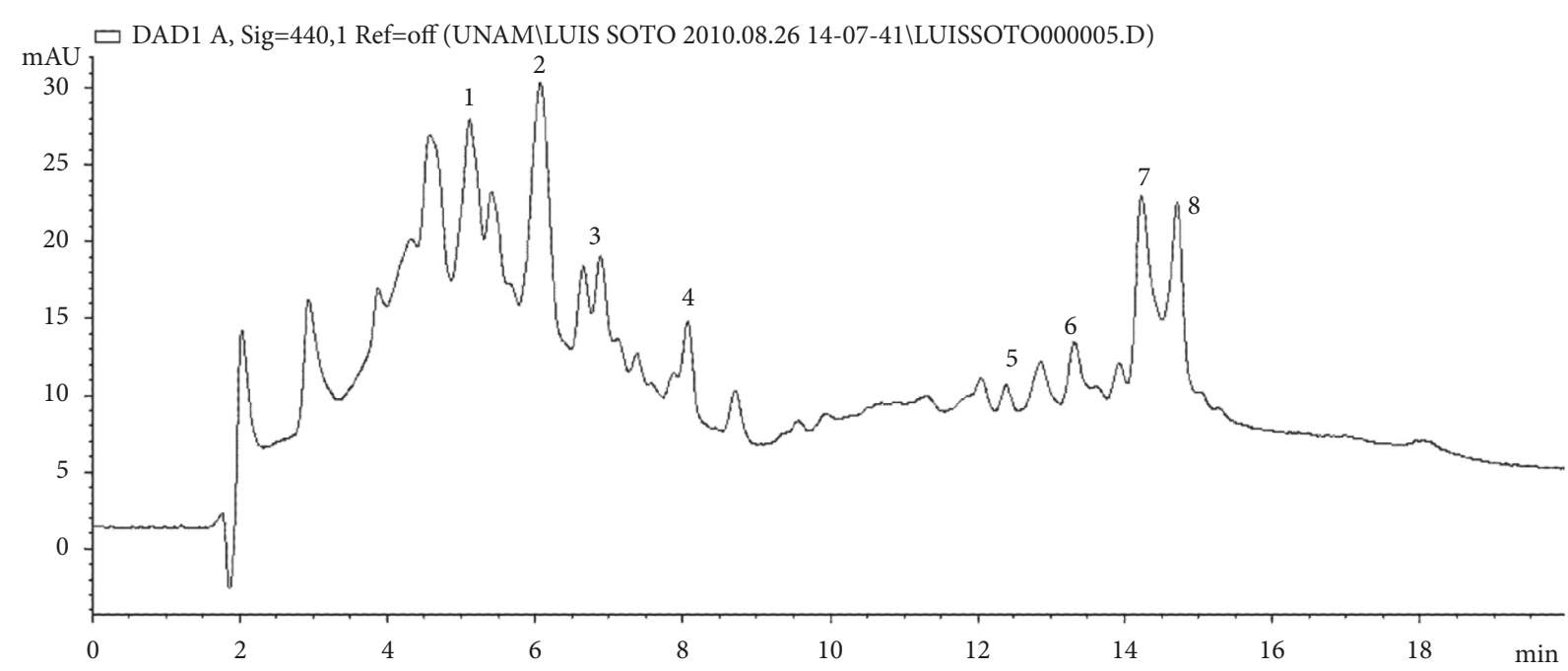

Figure 3: Chromatogram obtained from the sediment core 11. (1) Phaeophorbide- $a$, (2) Prasinoxanthin, (3) Diadinoxanthin, (4) Zeaxanthin, (5) Chlorophyll- $a$, (6) Phaeophytin- $a$, (7) Pyropheophytin- $a$, and (8) $\beta$-Carotene. 
examined and only traces of Alloxanthin $(8 \mathrm{ng} / \mathrm{g})$ in core 11 (Table 2). Diadinoxanthin was present in cores 1 and 3 , whereas Chl- $a$ and Phaeophytin- $a$ were only found in cores 10 and 11 . The core 11 exhibited the maximum pigment concentration $(10,309 \mathrm{ng} / \mathrm{g})$ in comparison with the other cores (Table 2), although in the core 3 there were also seven pigments identified in low concentrations.

With the Chi-square test ( $1 \%$ significance level), it is concluded that the characteristics of the substrate and temperature of each recovered core with respect to the pigments concentration and presence registered in the study area are independent (Chi-square test $p<0.0001$ ). In contrast, the estimated concentration for each identified pigment was significantly different between the cores analyzed (ANDEVA, $\mathrm{F}=5.31, p>0.006)$. However, no differences in the number of pigments recorded in each core were statistically significant (ANDEVA, $\mathrm{F}=1.36, p=0.26$ )

Tukey's multiple comparison tests $(p \leq 0.05)$ showed that cores from Great Pagoda core 1 and Oil Town cores 3 and 10 did not have significant statistical differences since they have a similar average pigment concentration. However, they differed from core 11 from Great Pagoda which had the highest average pigments concentration.

\section{Discussions}

The study of pigments in marine sediments is relatively recent $[6,7]$. Nevertheless, their analysis can provide vital information to determine the environmental conditions in a particular area. Chl- $a$ represents the most common photosynthetic pigment in nature. It has been the focus of numerous studies because it is the best chemical indicator of phytoplankton biomass and sources of organic carbon [24]. It is also known that Chl- $a$ depends on light energy to maintain its activity and therefore, some inferences can be made concerning the light and temperature conditions prevailing at the sites in which this photosynthetic pigment is detected [25]. Other pigments are considered secondary or accessory since they represent photoprotective cell membrane adaptations [26, 27].

Presumably, at depth in excess of $2,000 \mathrm{~m}$, as is the case of the GB, the light conditions are of total darkness. However, Reynolds and Lutz [28] have demonstrated that in the deep-ocean there are several sources of light, namely, bioluminescence, cosmic rays, and radioactivity. These authors conclude that the spectral composition of this light is not visible for the human vision but can be detected by deep abyssal dwellers and perhaps contributes in maintaining the activity of photosynthetic pigments. This fact may explain the presence of Chl- $a$ recorded in low concentrations in cores 10 and 11 (298 and $87 \mathrm{ng} / \mathrm{g}$, respectively, Table 2), occupying the third less abundant pigment (2.6\%). Although these cores were spatially separated by approximately 20 $\mathrm{km}$, they were collected at substrate covered by extensive bacterial mats and olive green sediments, indicative of the possible presence of Chl- $a$ or some of its derivatives (Phaeophytin- $a$, Phaeophorbide- $a$, or Pyrophaeophytin- $a$ ). It is worth mentioning that these findings add support to early assumptions that deep-sea hydrothermal ecosystems are capable of producing photosynthesis without relying on solar energy $[29,30]$. The facultative photosynthetic bacteria (producers of bacteriochlorophyll or other pigments) through a photochemical adaptation potential exploited at low levels of light take advantage of the photon flow emitted by hydrothermal fluids at extreme temperatures [30].

Chl- $a$ is characterized by being less thermostable compared to Chl- $b$ or $c$, depending on the environmental conditions. The Chl- $a$ molecule is highly susceptible, and therefore, its degradation is quite rapid [31,32]. Approximately 90\% of the Chl- $a$ is broken down into colorless products [24]. The degradation process is due to a combination of biotic factors (microorganisms or heterotrophic organisms) and abiotic factors (temperature, light intensity, and oxygen concentration) that foster this process, whose final products are known as chloropigments, phaeopigments, or degradation products $[24,26,33-36]$. In the vent system of GB, the Chl-a degradation process due to the prevailing extreme conditions resulted in the formation of Phaeophytin- $a$, Phaeophorbide$a$, and Pyrophaeophytin- $a$.

The Phaeophytin- $a$ is the product of the loss of magnesium in the Chl- $a$ molecule $[26,34]$. Afterward, its characteristic green color becomes an olive-brown tone. This pigment, like the Chl- $a$, was restricted to the cores 10 and 11 , but with a higher relative concentrations (386 and $1074 \mathrm{ng} / \mathrm{g}$, respectively). According to Yentsch [33], Chl- $a$ fractions are rapidly decomposed with the increase in water depth, the loss of light intensity, and the change in ambient temperature.

When Chl- $a$ loses a phytol group, Chlorophyllide is formed, which in turn eliminates a magnesium molecule giving rise to Phaeophorbide- $a[31,35]$ showing that the Chl- $a$ degradation to form Phaeophorbide- $a$ is initiated by extreme factors such as stress, light conditions, temperature changes, or their combined action. The presence of Chlorophyllide in all the cores obtained in the study area is probably due to extreme physicochemical conditions promoted by the hydrothermal fluids liberated at venting sites of GB [1]; such conditions seem to favor the formation of Phaeophorbide$a$, which had the second highest concentration $(3478 \mathrm{ng} / \mathrm{g}$ ) among the nine pigments identified here.

The Pyrophaeophytin- $a$ is the Chl- $a$ degradation final product which is formed by the decomposition of Phaeophytin- $a$, due to the loss of a carboxyl group, thus acquiring more stability and better preservation. Its presence indicates old and anoxic sediments with high organic carbon content $[7,24,26,33]$.

The high sedimentation rate of GB generates a thick layer of fine-grained sediments $(>400 \mathrm{~m})$ that favors the concentration of organic matter, reaching high organic carbon concentrations (3.4 to 12.4\%) [2, 3, 10, 12]. Edgcomb et al. [37] mentioned that the Basin is a hydrothermally active environment that includes vent plugs, filtrations, and anoxic sediments. These characteristics could explain the presence of Pyrophaeophytin- $a$ (3,514 ng/g), Chl- $a$ (298 ng/g), and Phaeophytin-a (618 ng/g) in the Great Pagoda core 11 and that of Pyrophaeophytin- $a(169 \mathrm{ng} / \mathrm{g})$ in the Oil Town core 3.

In the present study, of the nine pigments identified, five belong to the group of carotenoids: $\beta$-Carotene, Prasinoxanthin, Zeaxanthin, Alloxanthin, and Diadinoxanthin. In the Gulf of California, carotenoid downward flux is 
attributed to the predominance of Bacillariophyceae [14]. On the other hand, Van Dover [30] pointed out that diverse organisms that inhabit hydrothermal sites have the need to include carotenoid pigments in their diet, but they are unable to synthesize them. According to Nègre-Sadargues et al. [38], carotenoid pigments are obtained from bacteria, fungi, or plants. DeBevoise et al. [39] suggested that the carotenoids found in the crab eggs of Bythograea thermydron are produced in situ by chemoautotrophic bacteria present and are not derived from phytodetritus as one may expect.

$\beta$-Carotene is found in almost all algae except Cryptophytes and Rhodophyta and is produced by a large number of bacteria [36]. Its color is yellow, orange, or red and is the most abundant carotenoid in nature [27]. NègreSadargues et al. [38] and DeBevoise et al. [39] identified this pigment as one of the factors responsible for the coloration of some crustaceans, such as Bythograea thermydron and Rimicaris exoculata, both abundant in hydrothermal vent sites of the Mid-Atlantic Ridge. $\beta$-Carotene was present in all the sediment cores recovered at Great Pagoda and Oil Town sites, where extensive bacterial mats of yellow, orange, and red colors were detected. Diadinoxanthin has a yellow coloration which is probably formed by the conversion of the final allylic group of neoxanthin, and Prasinoxanthin is a dark pink pigment [36]. The main source of these pigments is the exoskeleton or the tissues of some species of macrocrustaceans or molluscs [22]. The sampled sites in GB probably involve a complex of chemoautotrophic bacterial consortiums capable of producing photosynthetic pigments [39-43].

Alloxanthin and Zeaxanthin are orange or yellow pigments that belong to the group of xanthophylls and are usually found in bacteria, algae, and higher plants or animals $[36,44]$. The presence of Alloxanthin in our study can again be ascribed to the existence of complex bacterial consortiums and to the occurrence of some copepods (e.g., Temora longicornis and Centropages hamatus) that concentrate this pigment in their digestive system [44]. On the other hand, Zeaxanthin can be an indicator of picocyanobacteria and cyanobacteria abundantly embedded in old sediments [45]. Zeaxanthin does not have photoadaptive properties, so its concentration in a cell can be constant despite changes in light conditions. Besides, it is so stable that it is considered a useful biomarker, even when the site conditions are oligotrophic including ancient sediments [45].

Another possible mechanism for the production of pigments or degradation products occurs during the digestive process of some gastropods such as Littorina littorea [46] which is distributed in the intertidal zone of the North Atlantic coasts. Thus, it cannot be ruled out that the pigments identified in the study area have a similar origin in bacteriovorus molluscs associated with hydrothermal vents such as Provanna laevis [13].

The processes of vertical distribution of phaeopigments in the ocean are not dismissed. Kalle [47] showed that seawater contains soluble pigments produced by phytoplankton metabolism. However, studies conducted by other authors $[26,33,48-51]$ did not reveal whether these pigments can be accumulated at deep hydrothermal vents without altering their structure. In GB, the $\delta 13 \mathrm{C}$ signature of TOC surficial sediments reveals depleted values (-32.0\%o.) for sulfur-rich sediments, while values are significantly enriched $(-18.0 \%)$ away from the vent, reflecting input of photosynthetic based carbon [13].

\section{Conclusions}

Free-living organisms are essential in hydrothermal systems for the production of pigments. They function as sinks of inorganic sulphides and reducing components and promote the production of organic carbon particles from inorganic carbon, by complex bacterial consortiums, zooplankters, and benthic organisms. The microorganisms inhabiting extreme thermal and chemical environments have a high diversity of metabolites and are essentially chemosynthetic. Although cores 11 and 10 were obtained from different zones, Great Pagoda and Oil Town, respectively, they both shared similar Beggiatoa spp. substrate mats. The same occurred in cores 1 and 3 from Great Pagoda and Oil Town, respectively, which presented large orange bacterial mats. Chl- $a$ and its derivatives (Phaeophytin- $a$, Phaeophorbide- $a$, and Pyrophaeophytin- $a$ ) attained their highest concentration in core Great Pagoda 11, branded by its olive green color containing black large bacterial mats. The presence and concentration of the extracted pigments varied among sites. There were significant statistical differences in the concentrations of pigments between cores. The nine photosynthetic pigments analyzed in this study seem to be a common feature in the surface sediments of the GB hydrothermal vent system whose presence and concentration under extreme thermal and chemical conditions essentially relies on the metabolism of a diversity of the chemoautotrophic bacterial consortium.

Guaymas Basin hydrothermal vents are rich in organic matter, sulphur, carbonates, and silicate materials. The photosynthetic pigments accumulated in the surface sediments at venting sites of the GB hydrothermal system are essentially of chemoautotrophic bacterial origin.

\section{Data Availability}

The datasets generated during and/or analysed during the current study are available from the corresponding author upon reasonable request.

\section{Conflicts of Interest}

The authors declare that there are no conflicts of interest regarding the publication of this paper.

\section{Acknowledgments}

Thanks are extended to H. Felbeck for his constructive comments to this publication. This contribution was greatly benefited by comments made by two anonymous reviewers. The authors express their gratitude to the members of the Harmful Microalgae Laboratory from Centro de Investigaciones Biológicas del Noroeste, S.C. (CIBNOR, S.C.) in La $\mathrm{Paz}, \mathrm{Baja}$ California Sur, for their assistance in the sample 
processing. Thanks are due to the Woods Hole Oceanographic Institution for their invitation to participate in the oceanographic cruise AT 15-38 on board of the R/V Atlantis. A special word of appreciation is due to the crew of the ship and the DSRV Alvin for their invaluable support during the oceanographic cruise. This study is part of the research program on hydrothermal vent ecology financed by the Instituto de Ciencias del Mar y Limnología, UNAM.

\section{References}

[1] K. Von Damm, J. Edmond, C. Measures, and B. Grant, "Chemistry of submarine hydrothermal solutions at Guaymas Basin, Gulf of California," Geochimica et Cosmochimica Acta, vol. 49, no. 11, pp. 2221-2237, 1985.

[2] B. R. Simoneit, "Hydrothermal petroleum: genesis, migration, and deposition in Guaymas Basin, Gulf of California," Canadian Journal of Earth Sciences, vol. 22, no. 12, pp. 1919-1929, 1985.

[3] G. Einsele, J. M. Gieskes, J. Curray et al., "Intrusion of basaltic sills into highly porous sediments, and resulting hydrothermal activity," Nature, vol. 283, no. 5746, pp. 441-445, 1980.

[4] A. C. Campbell and J. M. Gieskes, "Water column anomalies associated with hydrothermal activity in the Guaymas Basin, Gulf of California," Earth and Planetary Science Letters, vol. 68, no. 1, pp. 57-72, 1984.

[5] A. C. Campbell, J. M. Gieskes, J. E. Lupton, and P. F. Lonsdale, "Manganese geochemistry in the Guaymas Basin, Gulf of California," Geochimica et Cosmochimica Acta, vol. 52, no. 2, pp. 345-357, 1988.

[6] S. E. Palmer and E. W. Baker, "Copper porphyrins in deep-sea sediments: a possible indicator of oxidized terrestrial organic matter," Science, vol. 201, no. 4350, pp. 49-51, 1978.

[7] G. Kowalewska, "Algal pigments in sediments as a measure of eutrophication in the Baltic environment," Quaternary International, vol. 130, no. 1, pp. 141-151, 2005.

[8] N. Reuss, "Sediment pigments as biomarkers of environmental change," Organic Geochemistry, vol. 33, no. 12, pp. 1655-1665, 2005.

[9] P. Lonsdale, J. Bischoff, V. Burns, M. Kastner, and R. Sweeney, "A high-temperature hydrothermal deposit on the seabed at a gulf of California spreading center," Earth and Planetary Science Letters, vol. 49, no. 1, pp. 8-20, 1980.

[10] D. A. Bazylinski, J. W. Farrington, and H. W. Jannasch, "Hydrocarbons in surface sediments from a Guaymas Basin hydrothermal vent site," Organic Geochemistry, vol.12, no. 6, pp. 547-558, 1988.

[11] B. Simoneit, R. Leif, A. Sturz, A. Sturdivant, and J. Gieskes, "Geochemistry of shallow sediments in Guaymas Basin, gulf of California: hydrothermal gas and oil migration and effects of mineralogy," Organic Geochemistry, vol. 18, no. 6, pp. 765-784, 1992.

[12] G. De la Lanza-Espino and L. A. Soto, "Sedimentary geochemistry of hydrothermal vents in Guaymas Basin, Gulf of California, Mexico," Applied Geochemistry, vol. 14, no. 4, pp. 499-510, 1999.

[13] L. A. Soto, "Stable carbon and nitrogen isotopic signatures of fauna associated with the deep-sea hydrothermal vent system of Guaymas Basin, Gulf of California," Deep-Sea Research Part II: Topical Studies in Oceanography, vol. 56, no. 19-20, pp. 16751682, 2009.
[14] E. W. Baker and J. W. Louda, "Geochemistry of tetrapyrrole, tetraterpenoid, and perylene pigments in sediments from the Gulf of California: Deep Sea Drilling Project Leg 64, SITES 474, 477, 479, AND 481, and SCRIPPS Institution of Oceanography Guaymas Basin survey cruise LEG 3, sites 10G and 18G," in Initial reports DSDP, Part 2, J. R. Curray, D. G. Moore et al., Eds., vol. 64, pp. 789-814, U.S. Government Publishing Office, Washington, DC, USA, 1982.

[15] A. Teske, D. de Beer, L. J. McKay et al., "The guaymas basin hiking guide to hydrothermal mounds, chimneys, and microbial mats: complex seafloor expressions of subsurface hydrothermal circulation," Frontiers in Microbiology, vol. 7, p. 75, 2016.

[16] J. V. Byrne and K. O. Emery, "Sediments in the Gulf of California," Geological Society of America Bulletin, vol. 71, no. 1, pp. 983-1010, 1960.

[17] B. R. Simoneit, M. Mazurek, S. Brenner, P. Crisp, and I. Kaplan, "Organic geochemistry of recent sediments from Guaymas Basin, Gulf of California," Deep Sea Research Part A. Oceanographic Research Papers, vol. 26, no. 8, pp. 879-891, 1979.

[18] B. R. Simoneit and P. F. Lonsdale, "Hydrothermal petroleum in mineralized mounds at the seabed of Guaymas Basin," Nature, vol. 295, no. 5846, pp. 198-202, 1982.

[19] P. Lonsdale and K. Becker, "Hydrothermal plumes, hot springs, and conductive heat flow in the Southern Trough of Guaymas Basin," Earth and Planetary Science Letters, vol. 73, no. 2-4, pp. 211-225, 1985.

[20] A. Pearson, J. Seewald, and T. Eglinton, "Bacterial incorporation of relict carbon in the hydrothermal environment of Guaymas Basin," Geochimica et Cosmochimica Acta, vol. 69, no. 23, pp. 5477-5486, 2005.

[21] J. F. Grassle, "Hydrothermal vent animals: distribution and biology," Science, vol. 229, no. 4715, pp. 713-717, 1985.

[22] F. Vidussi, H. Claustre, J. Bustillos-Guzmàn, C. Cailliau, and J. Marty, "Determination of chlorophylls and carotenoids of marine phytoplankton: separation of chlorophyll a from divinylchlorophyll a and zeaxanthin from lutein," Journal of Plankton Research, vol. 18, no. 12, pp. 2377-2382, 1996.

[23] D. C. Montgomery and G. C. Runger, Probabilidad y Estadística Aplicadas a La Ingeniería, Mc Graw Hill, 1st edition, 1996.

[24] M. Szymczak-Żyła and G. Kowalewska, "Chloropigments $a$ in the Gulf of Gdańsk (Baltic Sea) as markers of the state of this environment," Marine Pollution Bulletin, vol. 55, no. 10-12, pp. 512-528, 2007.

[25] W. Gieskes, G. Kraay, and S. Tijssen, "Chlorophylls and their degradation products in the deep pigment maximum layer of the tropical North Atlantic," Netherlands Journal of Sea Research, vol. 12, no. 2, pp. 195-204, 1978.

[26] A. Herbland, "The deep phaeopigments maximum in the ocean: reality or illusion?" in Toward a Theory on Biological-Physical Interactions in the World Ocean, NATO ASI Series, pp. 157-172, 1988.

[27] G. Britton, "Structure and properties of carotenoids in relation to function.," The FASEB Journal, vol. 9, no. 15, pp. 1551-1558, 1995.

[28] G. T. Reynolds and R. A. Lutz, "Sources of light in the deep ocean," Reviews of Geophysics, vol. 39, no. 1, pp. 1-14, 2007.

[29] H. W. Jannasch and M. J. Mottl, "Geomicrobiology of deepsea hydrothermal vents," Science, vol. 229, no. 4715, pp. 717-725, 1985.

[30] C. L. Van Dover, The Ecology of Deep-Sea Hydrothermal Vents, Princeton University Press, 2000. 
[31] S. M. Gupte, H. M. El-Bisi, and F. J. Francis, "Kinetics of thermal degradation of chlorophyll in spinach puree," Journal of Food Science, vol. 29, no. 4, pp. 379-382, 1964.

[32] A. Van Loey, V. Ooms, C. Weemaes et al., "Thermal and pressure-temperature degradation of chlorophyll in Broccoli (Brassica oleracea L. italica) juice: a kinetic study," Journal of Agricultural and Food Chemistry, vol. 46, no. 12, pp. 5289-5294, 1998.

[33] C. S. Yentsch, "Distribution of chlorophyll and phaeophytin in the open ocean," Deep Sea Research and Oceanographic Abstracts, vol. 12, no. 5, pp. 653-666, 1965.

[34] S. J. Schwartz and J. H. Elbe, "Kinetics of chlorophyll degradation to pyropheophytin in vegetables," Journal of Food Science, vol. 48, no. 4, pp. 1303-1306, 1983.

[35] J. W. Heaton and A. G. Marangoni, "Chlorophyll degradation in processed foods and senescent plant tissues," Trends in Food Science \& Technology, vol. 7, no. 1, pp. 8-15, 1996.

[36] S. W. Jeffrey and M. Vest, "Introduction to marine phytoplankton and their pigment signatures," in Phytoplankton Pigments in Oceanography, S. W. Jeffrey, R. F. C. Mantoura, and S. W. Wright, Eds., pp. 37-84, UNESCO, Paris, France, 1997.

[37] V. P. Edgcomb, D. T. Kysela, A. Teske, A. de Vera Gomez, and M. L. Sogin, "Benthic eukaryotic diversity in the Guaymas Basin hydrothermal vent environment," Proceedings of the National Acadamy of Sciences of the United States of America, vol. 99, no. 11, pp. 7658-7662, 2002.

[38] G. Nègre-Sadargues, R. Castillo, and M. Segonzac, "Carotenoid pigments and trophic behaviour of deep-sea shrimps (Crustacea, Decapoda, Alvinocarididae) from a hydrothermal area of the Mid-Atlantic Ridge," Comparative Biochemistry and Physiology Part A: Molecular \& Integrative Physiology, vol. 127, no. 3, pp. 293-300, 2000.

[39] A. E. DeBevoise, J. J. Childress, and N. W. Withers, "Carotenoids indicate differences in diet of the hydrothermal vent crab Bythograea thermydron (Brachyura)," Marine Biology, vol. 105, no. 1, pp. 109-115, 1990.

[40] B. B. Jørgensen, "Distribution of colorless sulfur bacteria (Beggiatoa spp.) in a coastal marine sediment," Marine Biology, vol. 41, no. 1, pp. 19-28, 1977.

[41] A. Boetius and H. Felbeck, "Digestive enzymes in marine invertebrates from hydrothermal vents and other reducing environments," Marine Biology, vol. 122, no. 1, pp. 105-113, 1995.

[42] P. M. Biesiot and H. M. Perry, "Biochemical composition of the deep-sea red crab Chaceon quinquedens (Geryonidae): organic reserves of developing embryos and adults," Marine Biology, vol. 124, no. 3, pp. 407-416, 1995.

[43] M. Lotocka and E. Styczyńska-Jurewicz, "Astaxanthin, canthaxanthin and astaxanthin esters in the copepod Acartia bifilosa (Copepoda, Calanoida) during ontogenetic development," Oceanologia, vol. 43, no. 4, pp. 487-497, 2001.

[44] E. Antajan and S. Gasparini, "Assessment of Cryptophyceae ingestion by copepods using alloxanthin pigment: a caution," Marine Ecology Progress Series, vol. 274, pp. 191-198, 2004.

[45] T. S. Bianchi, E. Engelhaupt, P. Westman, T. Andrén, C. Rolff, and R. Elmgren, "Cyanobacterial blooms in the Baltic Sea: natural or human-induced?" Limnology and Oceanography, vol. 45, no. 3, pp. 716-726, 2000.

[46] D. Abele-Oeschger and H. Theede, "Digestion of algal pigments by the common periwinkle Littorina littorea L. (Gastropoda)," Journal of Experimental Marine Biology and Ecology, vol. 147, no. 2, pp. 177-184, 1991.
[47] K. Kalle, “Zum problem der Meereswasserfarbe," Annalen der Hydrographie und Maritimen Meteorologie, vol. 66, pp. 1-13, 1938.

[48] C. Yentsch and J. Ryther, "Absorption curves of acetone extracts of deep water particulate matter," Deep Sea Research (1953), vol. 6, pp. 72-74, 1959.

[49] J. B. SooHoo and D. A. Kiefer, "Vertical distribution of phaeopigments-I. A simple grazing and photooxidative scheme for small particles," Deep Sea Research Part A. Oceanographic Research Papers, vol. 29, no. 12, pp. 1539-1551, 1982.

[50] J. J. Cullen, "The deep chlorophyll maximum: comparing vertical profiles of chlorophyll a," Canadian Journal of Fisheries and Aquatic Sciences, vol. 39, no. 5, pp. 791-803, 1982.

[51] M. Vernet and C. J. Lorenzen, "The presence of chlorophyll $b$ and the estimation of phaeopigments in marine phytoplankton," Journal of Plankton Research, vol. 9, no. 2, pp. 255-265, 1987. 


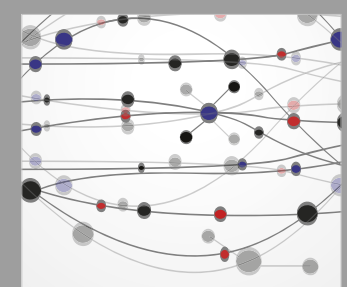

The Scientific World Journal
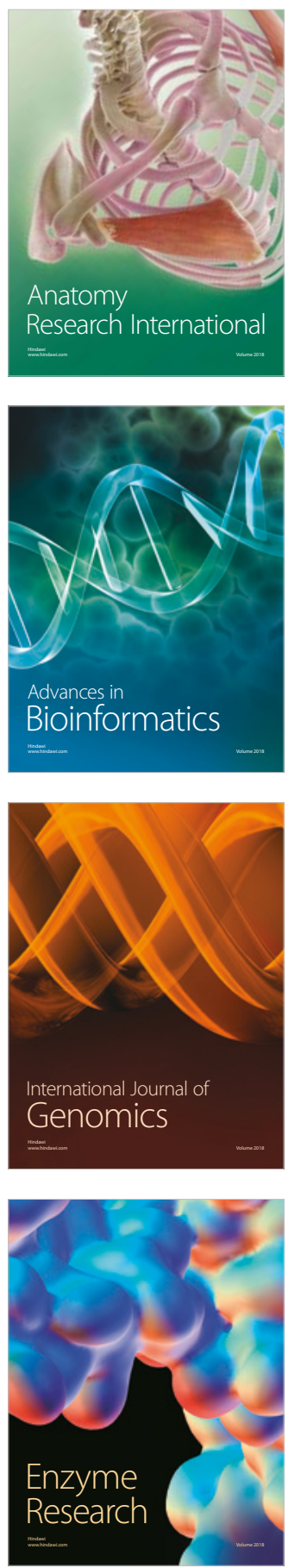
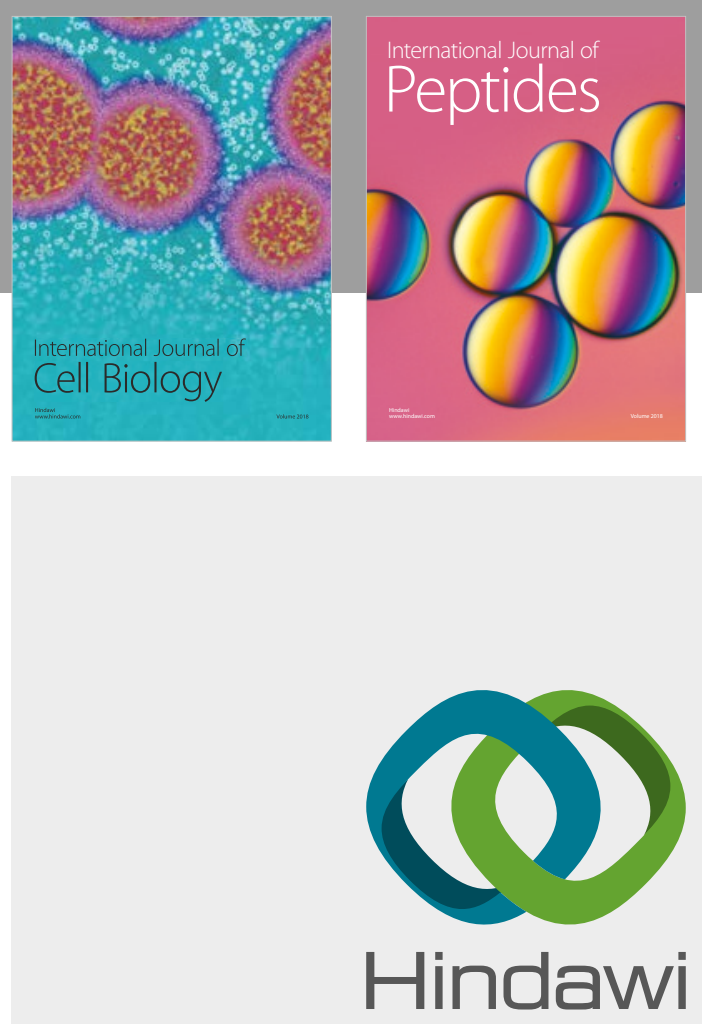

Submit your manuscripts at

www.hindawi.com
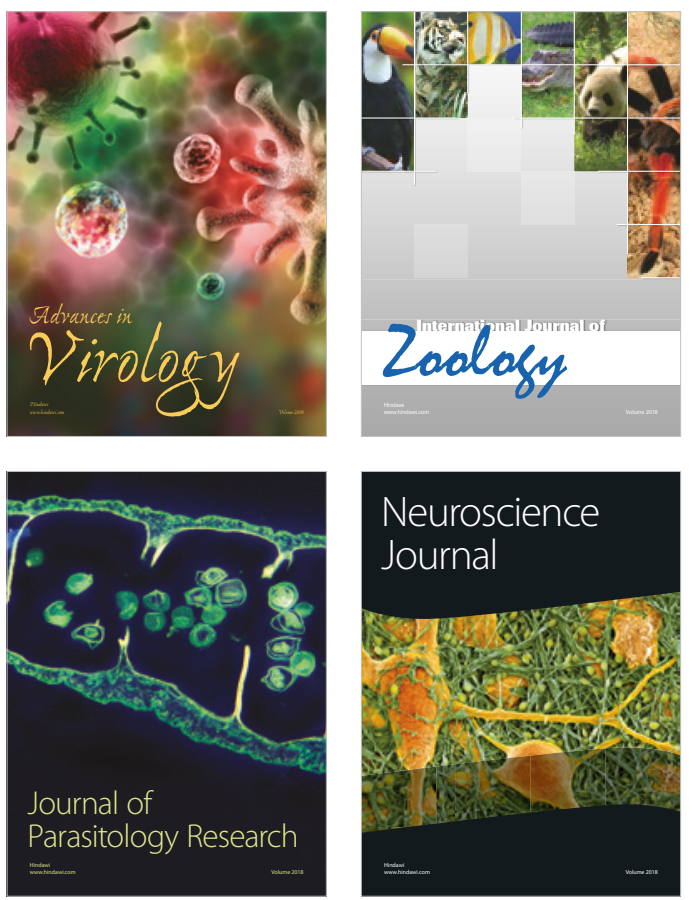
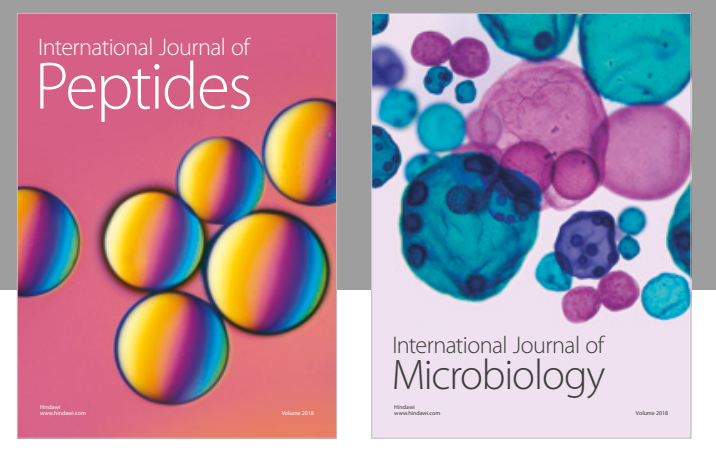

nternational Journal of Microbiology
Journal of
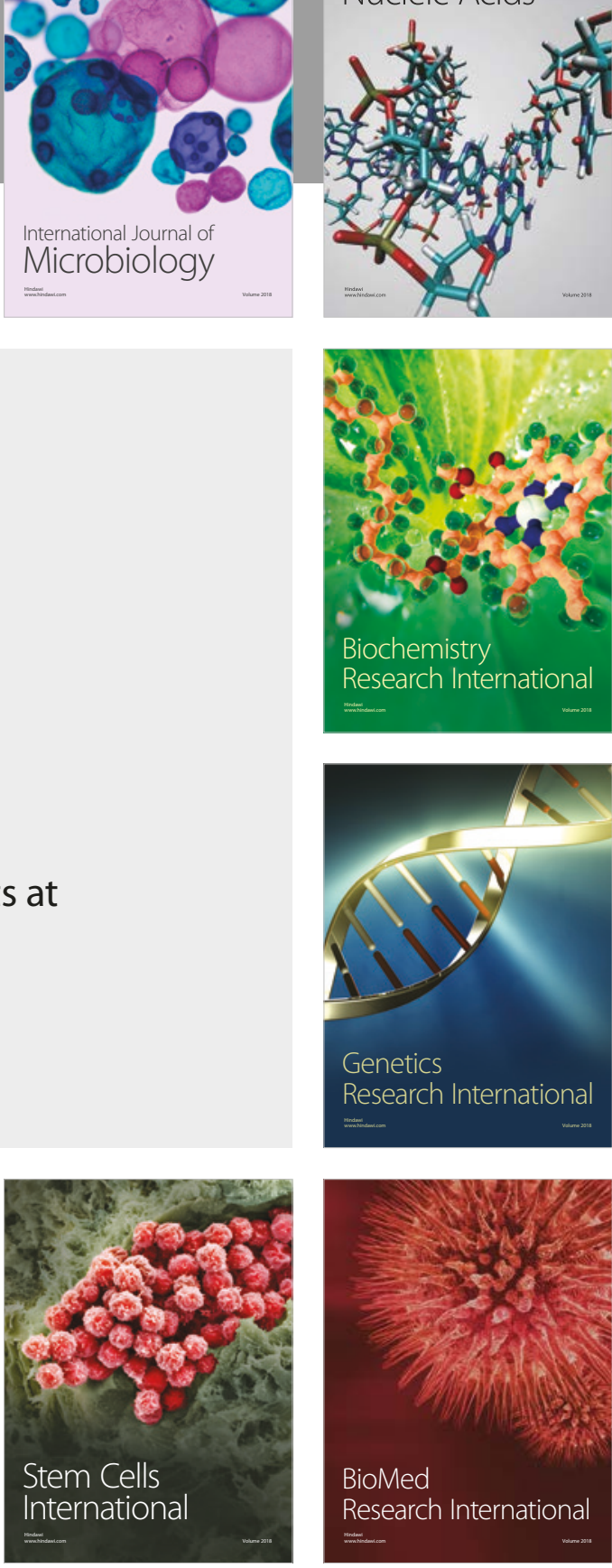
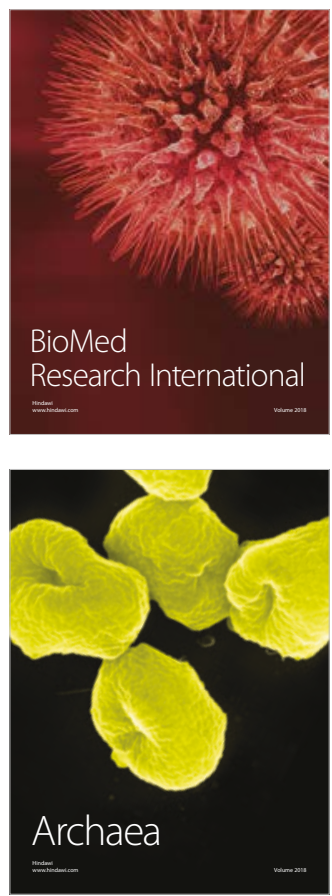